\title{
Moving Toward Universal Health Coverage: Four Decades Of Experience From The Iranian Health System
}

This article was published in the following Dove Press journal:

ClinicoEconomics and Outcomes Research

\section{Cyrus Alinia \\ Jalal Davoodi Lahijan (D)}

Department of Health Management and Economics, School of Public Health, Urmia University Of Medical Sciences, Urmia, Iran
Correspondence: Jalal Davoodi Lahijan Department of Health Management and Economics, School of Public Health, Urmia University of Medical Sciences, I Ith kilometer of Sero road, West Azarbaijan Province, Urmia 57I4783734, Iran Tel +989395928683

Email j.davoodi2020@gmail.com

\begin{abstract}
Universal health coverage (UHC) during the past decade has become the main goal of the World Health Organization. Access to health services, without suffering financial hardship for the patients, constitutes the key foundation definition of UHC and its three dimensions: population coverage, service coverage, and financial protection. Iranian health policymakers have purposefully or non-purposefully been pursued the UHC goals during the last four decades by the following macro plans: Health corps, establishing and expanding Health-Care Networks, Law of Universal Health and Social Security Insurances, Family Physician, and Health Transformation Plan. In this paper, we evaluated the situation of UHC in the Iranian health system, presented the weaknesses, strengths, and challenges faced with the health system in its implementation, and finally provided some policy recommendations to complete implementation of the policy in the country.
\end{abstract}

Keywords: universal health coverage, health policy, Iranian health system, health transformation plan

\section{Introduction}

Country of the Islamic Republic of Iran, with a population of over 80 million, is located in the Eastern Mediterranean region. Equitable access to health-care services respected as a right in article 29 of Iran's constitution for all Iranian citizens. ${ }^{1}$ In this regard, Iran's health system that has a history of more than a century has been committed to pursuing this goal through the adoption of micro and macro policies by 47 medical sciences universities across the country. During the last century, Iran's health system changed its name several times; Department of Health and Charity Affairs [1911-1941], Ministry of Health [1941-1976], Ministry of Health and Welfare [1976-1981], Ministry of Health [1981-1985], Ministry of Health and Welfare [1985-1986], and finally, Ministry of Health and Medical Education since $1985 .^{2}$ Primary health-care services in Iran are provided through a national health-care network consisting of health houses, rural and urban health centers, urban, provincial, and regional hospitals. ${ }^{1-4}$ Iranian health policymakers have purposefully or non-purposefully been pursued the Universal Health Coverage (UHC) goals during the last four decades by the following macro plans: ${ }^{4,5}$ (1) Health corps, (2) establishing and expanding health-care networks, (3) law of universal health and social security insurances, (4) family physician and referral system plan, and (5) health transformation plan (HTP). 


\section{Health Corps}

To provide the rudimentary health and sanitation services, the ministry of health in collaboration with the Ministry of War had appointed that graduates of medical, dental, veterinary and health-care affairs to spend their compulsory military service period in the deprived rural areas from 1964 to 1975 . This policy had succeeded in covering about 6 million of the rural inhabitants, 21 percent of the total population, which had established 1422 health centers using 1290 general physicians and other health personnel. During implementing this plan, the mortality rates of neonatal and children had dramatically decreased, and Iran's population had risen from 25 to 30 million. ${ }^{6,7}$

\section{Establishing And Expanding Health- Care Networks}

Iran's health-care network has been developed gradually across the country since 1985, after the success of the establishment project of health-care houses in Urmia city in the years 1972 to 1976 . The main goal of the plan was providing equitable access of all communities to primary health-care, especially in rural areas. The health-care network expanded its primary health-care services to all rural and cities of the country during the time. ${ }^{8}$ As shown in Figure 1, primary health-care has been providing by health houses in rural and health posts in urban. In these centers, 80 percent of patients' health need is met and the rest is referred to the higher levels. ${ }^{9}$ Number of health houses and posts based on the national standards/protocol is about 17,300 and 300 , respectively. ${ }^{3,10}$ However, many patients bypass these rural and urban health centers and directly access district, university, or private hospitals at higher levels.

Secondary health cares have been providing by district hospitals in each county. These hospitals must have at least five specialties including general surgery, pediatrics, Internal medicine, obstetrics, and gynecology that provide to patients referred from primary level of referral system. ${ }^{11}$

This policy has been developed and implemented to meet the World Health Organization (WHO) slogan, Health For All, which was expressed at the Alma-Ata conference in the year of $1978 .{ }^{9}$ So that, a need-based health-care services package defined and prepared. This services package covers health education, vaccination, family planning, maternal and child cares, environmental health, local diseases control, common diseases treatment, and basic medicines. This plan has allocated about 8-12 percent of the total national health expenditure. ${ }^{9}$ Currently, about 94 percent of Iran's population is covered by healthcare networks. $^{12,13}$ However, health-care out-of-pocket payment from the beginning of the plan to 2001 was increased from 48 to 58 percent, which was one of the most important challenges facing the health system of Iran. ${ }^{3}$ Designing of health-care networks has been carried

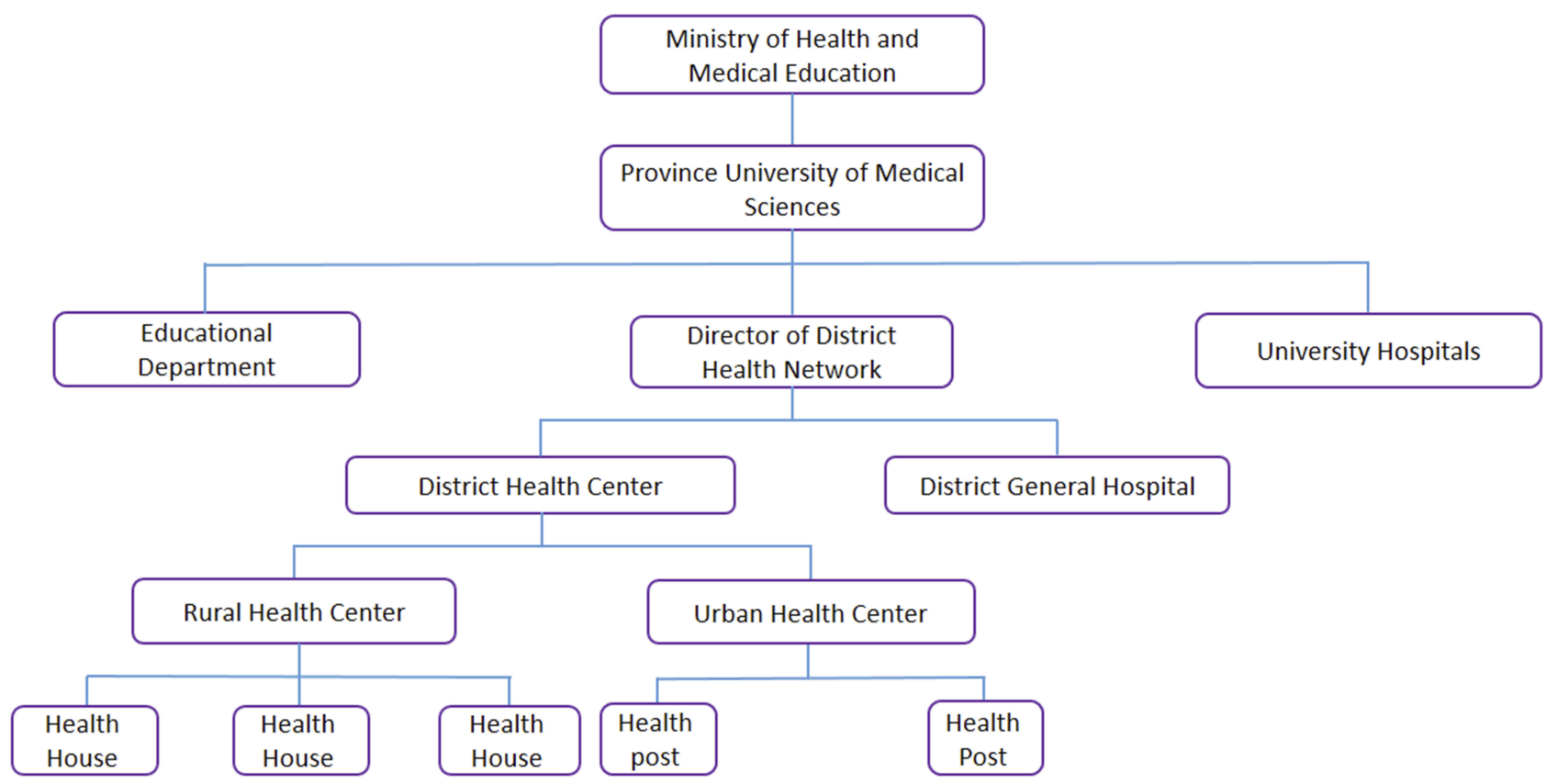

Figure I The structure of Iran's health-care network. 
out in accordance with the standards established by the WHO, where the following items were observed: good access of population to the services, providing the acceptable services from the viewpoint of the community, defining a comprehensive package of services, and actively participating of community in the health affairs.

\section{Law Of Universal Health And Social Security Insurances}

Iran's parliament passed two historical laws of the establishment of the Social Security Organization in 1989 and Universal Health Insurance in 1993 to increase the population coverage of health-care system. These organizations have been committed to providing insurance facilities particularly to Iranian workers, government employees, deprived people, and rural residents. Currently, out of 80 million population of Iran, Social Security Organization, Health Insurance, and Armed Forces Insurance cover more than $34.2,{ }^{14} 34.3,{ }^{15}$ and 4 million ${ }^{16}$ people, respectively. So, by implementing the insurance laws, the population coverage rate has been increased from 40 percent in 1994 to 85 percent in 1995 and 90 percent in $2016 .{ }^{4}$ Both the Social Security and the Health Insurance Organizations cover about 90 percent of inpatient and 70 percent of outpatient costs. According to the World Bank report, these laws lead to a decrease in healthcare out-of-pocket expenditures from 53.6 to 49.6 percent only during 1 year after implementing the policy. ${ }^{4}$ The most important obstacles in that time to reaching a sustainable UHC were regressive financing, fragmented pools, nontransparent financial flow, deficit payment system, non-prevention-oriented policies, uncontrolled demands, and low efficiency. ${ }^{17}$

\section{Family Physician And Referral System Plan}

The family physician program was implemented to develop a referral system, leveling services, and demand control of complicated health-care services through a health group consisting of a general physician, midwife, family health expert, and Behvarz in rural areas and cities with less than 20,000 people in 2004. Behvarz is defined as an inexpensive workforce and a Community Health Worker in Iran, which officially worked with the primary preventive health-care network. The main goals of this national plan were strengthening the referral system, increasing accountability, services coverage, access to primary health care, and reducing unnecessary health-care costs. By implementing this program, the basic service package provided in the health network system was redefined and adjusted according to the community's needs. The new package added health education, elderly cares, community health, and occupational health care to the old package. After running this program, insurance coverage was increased from 27 to 97 percent in rural and urban with 20,000 or fewer inhabitants, ${ }^{18}$ which resulted in a reduction of more than 6 percent in health-care expenses and increase equity in health-care delivery. ${ }^{19}$

Unfortunately, this program remains relatively silent after twelve years and is only operating in Mazandaran and Shiraz provinces. The major reasons for the policy failure were lack of internal cooperation, misunderstandings of the program by executives, lack of adequate budget, and lack of proper partnership between the health insurance organizations and service providers. ${ }^{20,21}$

\section{Health Transformation Plan (HTP)}

This comprehensive and national policy has been done to achieve the health-related goals of the fifth five-year national development plan in 2014 and has continued so far. The major objectives of the HTP are increasing the population coverage of basic health insurances, increasing the quality of cares provided in governmental hospitals, reducing the hospital cares out-of-pocket payments, increasing access to the primary healthcares, and updating the relative value units of medical cares and its tariffs. This plan has covered about an additional 10 million Iranian people, 12.5 percent of the total population, that did not have any health insurance and most of them are relatively deprived. HTP also decreased inpatient out-of-pocket payments from 37.5 to 8.5 percent $^{22}$ and total health-care outof-pocket costs from 58 to 47.5 percent. $^{23}$ Table 1 shows the changes in UHC representing indicators of Iran's health system between the years of 1990 and 2015.

\section{Challenges Faced With Iran's Health System In Full Implementation Of UHC}

As we show in Table 1, Iran's health system has progressed toward the implementation of the UHC program by increasing the coverage of health-care services and also eliminating the affordability barriers through reducing the out-of-pocket expenditures and scaling-up the population coverage of health insurances. But it still has a 
Table I UHC-Related Indicators Of Iranian Health System From 1990 To 2015

\begin{tabular}{|c|c|c|c|c|}
\hline \multirow[t]{2}{*}{ Indicators } & \multicolumn{3}{|l|}{ Years } & \multirow[t]{2}{*}{ References } \\
\hline & 1990 & 2000 & 2015 & \\
\hline Out-of-pocket as percent of current health expenditure & - & 59.6 & 39.7 & 24 \\
\hline Out-of-pocket expenditures per capita in US\$ & - & 47.8 & 145.2 & 25 \\
\hline Percent of health insurance coverage & 21 & 85 & 95 & $26-29$ \\
\hline Life expectancy at birth for both gender & 67.8 & 70 & 74 & 30 \\
\hline Healthy life expectancy at birth for both gender & 57.4 & 61.8 & 66.5 & 31,32 \\
\hline Under 5 mortality rates (per 1000 live births) & 93.4 & 77.5 & 42.2 & 33 \\
\hline Maternal mortality rate (per 100,000 live birth) & 1.39 & 0.59 & 0.27 & 34 \\
\hline Burden of non-communicable diseases (per 100,000 population) & 18,705 & 17,667 & $|8,04|$ & 34 \\
\hline Burden of communicable diseases (per 100,000 population) & 13,908 & 5,311 & 3,071 & 34 \\
\hline
\end{tabular}

Abbreviation: US\$, United States Dollar.

considerable distance with the full UHC implementation. Review the list of successful countries in the implementation of full UHC show that there is no statistically significant relationship between the per capita income and success in achieving the full UHC. ${ }^{35}$ For example, Chile, South Korea, Malaysia, Rwanda, Mexico, and Thailand which are low- or middle-income countries, along with the countries of the Organization for Economic Co-operation and Development have also achieved remarkable success in implementing the UHC program during the last decade. ${ }^{35,36}$ Despite running the numerous micro and macro health-care promotion policies during the last three decades, the Iranian health system has not yet reached the acceptable level of UHC. This can be due to two main reasons:

Firstly, there is not a defined proper health-care services package that covers and responses to all primary health-care needs. The services which are currently delivering are not totally integrated into the health-care system and there is a fragmented and uneven system which in that each of the basic health insurance organizations is providing the different service packages with different financial coverage. Secondly, Iran's health system does not receive enough financial support from the government, so that share of public resources in financing the health system was about the 49.5 percent in 2014, but this value for the Eastern Mediterranean Regional of WHO and the world were 50 and 59 percent, on average, respectively. ${ }^{30}$

Surveys have shown that the value of catastrophic cost is between 6 and 24 percent, ${ }^{37-40}$ impoverishment costs range from 1.5 to 11 percent, and also Fair Financial Contribution index is reported as 0.57 to 0.83 in various regions of Iran. ${ }^{38,41,42}$ All of these evidences confirm the unacceptable level of financial protection of Iranian patients. In addition, not only the percent of Gross Domestic Product spent on health in Iran is lower than the global average, 8 versus 15 percent, but also, more importantly, lack of a scientific, transparent, and costeffective priority-setting has led to a considerable resource wasting and deadweight loss. Considering the UHC goals, the greatest strengths of the country's health system is health insurance coverage, which has recently been achieved by HTP implementation and all of the community has a possibility to have health insurance unless they are unwilling to become insured. In general, it can be claimed that the UHC cube in Iran is nearly completed in its population coverage dimention, but the financial and service coverage dimensions are still very poor. The experiences of successful countries have shown that the better identifying the challenges ahead of the health system will pave the way fo achieving UHC goals. ${ }^{43,44}$ It seems that a weak purchaser-provider split in Iran has led to decrease in efficiency of services delivery sector due to the lack of competitive space between the providers. This monopoly power has made ineffective many of cost control policies. So, along with creating and strengthening sustainable financing strategies, increasing access to providers should also be pursued in a balanced way. ${ }^{21}$

For this purpose, by dividing Iran's health system into two parts of the provider (the Ministry of Health) and the buyer (health insurance organizations) of health services, and considering the four main functions of the health system, namely, the stewardship, financing, production, and services delivery, we present the barriers of Iran's health system to achieve the full UHC implementation in Figure 2. 


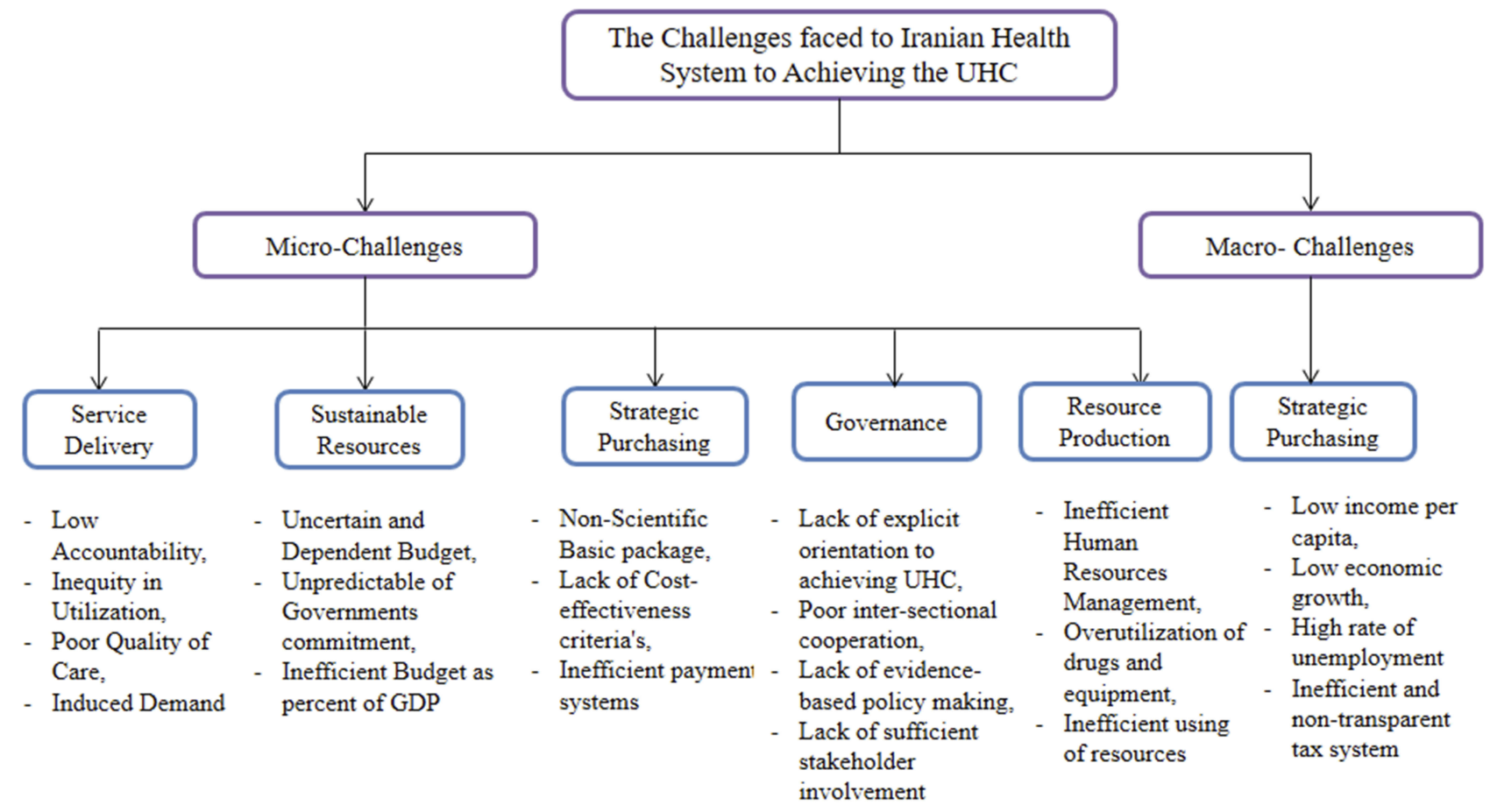

Figure 2 The challenges faced by the Iranian health system in achieving UHC.

\section{Policy Recommendations}

To overcome the most important barriers to achieving UHC in the Iranian health system, the following policies should be followed:

Firstly, integrating the multiple health insurances could be a key policy in solving some of the challenges and problems, because it makes it possible to define a single cost-effective health-care package, ${ }^{45}$ can solve the problem of population's dual coverage, ${ }^{46}$ can develop equity in health-care financing through using the progressive financing policy, ${ }^{46,47}$ and it can also identify and cover groups without insurance at a faster rate. ${ }^{48}$

Table 2 The Policy Recommendations To Achive Complete UHC

\begin{tabular}{|l|l|l|}
\hline $\begin{array}{l}\text { UHC } \\
\text { Dimensions }\end{array}$ & Policy Recommendation & Reference \\
\hline $\begin{array}{l}\text { Financial } \\
\text { Protection }\end{array}$ & $\begin{array}{l}\text { Integrating the multiple health } \\
\text { insurances }\end{array}$ & $50-53$ \\
\hline $\begin{array}{l}\text { Services } \\
\text { Coverage }\end{array}$ & $\begin{array}{l}\text { Integrating the multiple health } \\
\text { insurances }\end{array}$ & $50-59$ \\
- Resource allocation & Reforming the referral system & \\
\hline $\begin{array}{l}\text { Population } \\
\text { Coverage }\end{array}$ & $\begin{array}{l}\text { Reforming the referral system } \\
\text { Resource allocation }\end{array}$ & $53-57,60,61$ \\
\hline
\end{tabular}

Secondly, using scientific tools in resource allocation such as league table can significantly improve the efficiency and performance of Iran's health system, which requires the replacement of current managers who have conflicts of interests with experienced experts in the fields of health economics, policymaking, and health-care managers. Since the main problem of the health system regarding the budget is related to how to spend the resources, not its adequacy, the benefits of such a policy are in keeping with the UHC's goals. By applying this policy, the limited resources will be dedicated to cost-effective interventions, the health-care out-of-pocket payments will be decreased, and finally, health metrics will be elevated.

Thirdly, reforming the referral system which currently works badly can control the increasing health-care expenditures and supplier-induced demand which subsequently decrease the out-of-pocket payments (Table 2). ${ }^{49}$

\section{Disclosure}

The authors report no conflicts of interest in this work.

\section{References}

1. Khangah HA, Jannati A, Imani A, Salimlar S, Derakhshani N, Raef B. Comparing the health care system of Iran with various countries. Health Scope. 2017;6(1):e34459.

2. Azizi MH. The Historical Backgrounds of the Ministry of Health Foundation in Iran. Arch Iran Med. 2007;10(1):119-123. 
3. Organization WH. Health System Profile, Islamic Republic of Iran. Regional health systems observatory, WHO eastern Mediterranean regional office; 2006.

4. Davari M, Haycox A, Walley T. The Iranian health insurance system; past experiences, present challenges and future strategies. Iran $J$ Public Health. 2012;41(9):1.

5. Sajadi HS, Majdzadeh R. From primary health care to universal health coverage in the Islamic Republic of Iran: a journey of four decades. Arch Iran Med. 2019;22:5.

6. Bash KW, Bash-Liechti J. Developing Psychiatry: Epidemiological and Social Studies in Iran 1963-1976. Vol. 43. Springer Science \& Business Media; 2012.

7. Wolstenme G, O'Connor M. Teamwork for world health. Paper presented at: A Ciba Foundation Symposium in honour of Professor S. Arlunkal, J \& J A. Churchill, London; 1971.

8. Malekafzali H. Primary health case in Islamic Republic of Iran. J Sch Public Health Inst Public Health Res. 2014;12(2):1-10.

9. Gressani D, Saba J, Fetini H, Rutkowski M, Maeda A, Langenbrunner J. Islamic Republic of Iran Health Sector Review, Volume I: Main Report. The World Bank Group. Vol. 1. Middle East and North Africa: Human Development Sector; 2007:1575-1581.

10. Malekafzali H. Primary health care in the rural area of the Islamic Republic of Iran. Iran J Public Health. 2009;38(Suppl 1):69-70.

11. Gressani D, Larbi H, Fetini H. Islamic Republic of Iran Health Sector Review, Volume II: Background Sections. Washington, DC: The World Bank Group; 2008.

12. Dye C, Reeder JC, Terry RF. Research for universal health coverage. Sci Transl Med. 2013;5(199):199ed113-199ed113. doi:10.1126/scitranslmed. 3006971

13. A compilation : global PHM secretariat B, India the present and future of primary health care in iran.

14. Center of Statistics and Strategic Information of Ministry of Cooperatives Labour and Social Welfare, Statictical. Special Issue of Social Security Weak, Tehran. Center of Statistics and Strategic Information Publication. (In persian). 2014.

15. Ghasemi F. Ministry of Cooperatives, Labour and Social Welfare Statistics 2012. Tehran:Ministry of Cooperatives, Labour and Social Welfare. (in Persian). 2012.

16. Olyaeemanesh A. National Health Account Islamic Republic of Iran 2008. Tehran:Sarneveshsazan Publication. (in Persian). 2012.

17. Ibrahimipour H, Maleki M-R, Brown R, Gohari M, Karimi I, Dehnavieh R. A qualitative study of the difficulties in reaching sustainable universal health insurance coverage in Iran. Health Policy Plan. 2011;26(6):485-495. doi:10.1093/heapol/czq084

18. Khayyati F, Motlagh ME, Kabir M, Kazemeini H, Gharibi F, Jafari N. The role of family physician in case finding, referral, and insurance coverage in the rural areas. Iran J Public Health. 2011;40(3):136.

19. Azami-Aghdash S, Tabrizi J-S, Mohseni M, Naghavi-Behzad M, Daemi A, Saadati M. Nine years of publications on strengths and weaknesses of family physician program in rural area of Iran: a systematic review. J Anal Res Clin Med. 2016;4(4):182-195. doi:10.15171/jarcm.2016.032

20. Kazemian M, Kavian TF. Assessment of access to health care in family physician program with a comprehensive health care approach. Health Inf Manag. 2016;304-309.

21. Takian A, Rashidian A, Doshmangir L. The experience of purchaserprovider split in the implementation of family physician and rural health insurance in Iran: an institutional approach. Health Policy Plan. 2015;30(10):1261-1271. doi:10.1093/heapol/czu135

22. Arab-Zozani M. Health sector evolution in Iran; A short review. Evidence Based Health Policy Manage Econ. 2017;1(3):193-197.

23. Piroozi B, Moradi G, Nouri B, Bolbanabad AM, Safari H. Catastrophic health expenditure after the implementation of health sector evolution plan: a case study in the west of Iran. Int $J$ Health Policy Manag. 2016;5(7):417. doi:10.15171/ijhpm.2016.31
24. Available from: http://www.who.int/gho/health_financing/out_of pocket_spending/en/. Accessed October 10, 2019.

25. Available from: http://apps.who.int/gho/data/node.main. GHEDOOPpcUSSHA2011?lang=en. Accessed October 10, 2019.

26. Savedoff WD, Gottret P. Governing Mandatory Health Insurance: Learning from Experience. The World Bank; 2008.

27. Organization WH. Health Systems Profile-Islamic Republic of Iran Regional Health Systems Observatory-EMRO: Executive Summary. World health organization; 2000.

28. Rashidian A, Khosravi A, Khabiri R, et al. Islamic Republic of Iran's Multiple Indicator Demographic and Health Survey. IrMIDHS) Tehran: Ministry of Health and Medical Education; 2010.

29. Bazyar M, Rashidian A, Kane S, Mahdavi MRV, Sari AA, Doshmangir L. Policy options to reduce fragmentation in the pooling of health insurance funds in Iran. Int J Health Policy Manag. 2016;5 (4):253. doi:10.15171/ijhpm.2016.12

30. Organization WH. World Health Statistics. Geneva: World Health Organization; 2014:2014.

31. Available from: http://gamapserver.who.int/gho/interactive_charts/ $\mathrm{mbd} /$ hale_1/atlas.html. Accessed October 10, 2019.

32. Salomon JA, Wang H, Freeman MK, et al. Healthy life expectancy for 187 countries, 1990-2010: a systematic analysis for the global burden disease study 2010. The Lancet. 2012;380(9859):2144-2162. doi:10.1016/S0140-6736(12)61690-0

33. Available from: https://data.worldbank.org/indicator/SH.DYN. MORT. Accessed October 10, 2019.

34. Available from: http://ghdx.healthdata.org/gbd-results-tool. Accessed October 10, 2019.

35. Savedoff WD, de Ferranti D, Smith AL, Fan V. Political and economic aspects of the transition to universal health coverage. The Lancet. 2012;380(9845):924-932. doi:10.1016/S0140-6736 (12)61083-6

36. Knaul FM, Arreola-Ornelas H, Méndez-Carniado O, et al. Evidence is good for your health system: policy reform to remedy catastrophic and impoverishing health spending in Mexico. Salud Publica Mex. 2007;49:s70-s87.

37. Amery H, Jafari A, Panahi M. Determining the rate of catastrophic health expenditure and its influential factors on families in Yazd Province. J Health Administration. 2013;16:52.

38. Karami M, Najafi F, Karami Matin B. Catastrophic health expenditures in Kermanshah, west of Iran: magnitude and distribution. $J$ Res Health Sci. 2009;9(2):36-40.

39. Kavosi Z, Rashidian A, Pourreza A, et al. Inequality in household catastrophic health care expenditure in a low-income society of Iran. Health Policy Plan. 2012;27(7):613-623. doi:10.1093/heapol/ czs001

40. Sabermahani A, Vaeze Mahdavi M, Hadian M, Asadi-Lari M. Catastrophic health expenditures and its determinants among households in Tehran in 2011, Urban HEART-2 study. Razi J Med Sci. 2014;21(126):15-26.

41. Ghorbanian A, Rashidian A, Lankarani KB, Kavosi Z. The prevalence and determinants of catastrophic health expenditures in Iran: a systematic review and meta-analysis. Health Scope. 2017. (In Press). doi:10.5812/jhealthscope. 63210

42. Kavosi Z, Keshtkaran A, Hayati R, Ravangard R, Khammarnia M. Household financial contribution to the health system in Shiraz, Iran in 2012. Int J Health Policy Manag. 2014;3(5):243. doi:10.15171/ ijhpm.2014.87

43. Missoni E, Solimano G. Towards universal health coverage: the Chilean experience. World Health Rep. 2010.

44. Yu H. Universal health insurance coverage for 1.3 billion people: what accounts for China's success? Health Policy. 2015;119(9):11451152. doi:10.1016/j.healthpol.2015.07.008

45. Sobczak A. Opportunities for and constraints to integration of health services in Poland. Int J Integr Care. 2002;2. 
46. Meng Q, Fang H, Liu X, Yuan B, Xu J. Consolidating the social health insurance schemes in China: towards an equitable and efficient health system. The Lancet. 2015;386(10002):1484-1492. doi:10.1016/S01406736(15)00342-6

47. Wang HS. Historical Development of NHI in Taiwan: DeFamilialization Path of Welfare Politics. Springer: Familial Foundations of the Welfare State; 2017:107-137.

48. Research IroIsNIoH. Universal Health Coverage in Iran. Iran's National Institute of Health Research; 2014.

49. Delnoij D, Van Merode G, Paulus A, Groenewegen P. Does general practitioner gatekeeping curb health care expenditure? J Health Serv Res Policy. 2000;5(1):22-26. doi:10.1177/135581960000500107

50. Hashemi MS, Irajpour A, Abazari P. Improving quality of care in hemodialysis: a content analysis. J Caring Sci. 2018;7(3):149. doi: $10.15171 /$ jcs. 2018.024

51. Blanchet K, Gordon I, Gilbert CE, Wormald R, Awan H. How to achieve universal coverage of cataract surgical services in developing countries: lessons from systematic reviews of other services. Ophthalmic Epidemiol. 2012;19(6):329-339. doi:10.3109/09286586.2012.717674

52. Chernichovsky D, Ofer G, Potapchik E. Health sector reform in Russia: the heritage and the private/public mix. MOCT-MOST. 1996;6(3):125-152. doi:10.1007/BF02430967

53. Uzochukwu B, Ughasoro M, Etiaba E, Okwuosa C, Envuladu E, Onwujekwe O. Health care financing in Nigeria: implications for achieving universal health coverage. Niger J Clin Pract. 2015;18 (4):437-444. doi:10.4103/1119-3077.154196
54. Liu Y, Hsiao WC, Eggleston K. Equity in health and health care: the Chinese experience. Soc Sci Med. 1999;49(10):1349-1356. doi:10.1016/ S0277-9536(99)00207-5

55. Collins C, Araujo J, Barbosa J. Decentralising the health sector: issues in Brazil. Health Policy. 2000;52(2):113-127.

56. Chuma J, Okungu V. Viewing the Kenyan health system through an equity lens: implications for universal coverage. Int J Equity Health. 2011;10(1):22. doi:10.1186/1475-9276-10-22

57. Jakovljevic MB. Resource Allocation Strategies in Southeastern European Health Policy. Springer; 2013.

58. Pannarunothai S, Srithamrongsawat S, Kongpan M, Thumvanna P. Financing reforms for the Thai health card scheme. Health Policy Plan. 2000;15(3):303-311. doi:10.1093/heapol/15.3.303

59. Eaton J, McCay L, Semrau M, et al. Scale up of services for mental health in low-income and middle-income countries. The Lancet. 2011;378(9802):1592-1603. doi:10.1016/S0140-6736(11)60891-X

60. Kutzin J, Barnum H. Institutional features of health insurance programs and their effects on developing country health systems. Int $J$ Health Plann Manage. 1992;7(1):51-72. doi:10.1002/(ISSN)1099-1751

61. Chamberlain LJ, Hughes DC, Bishop JS, Matsuda DH, Sassoubre L. Universal health care coverage for children: impact on pediatric health care providers. J Health Care Poor Underserved. 2005;16 (4):622-633.
ClinicoEconomics and Outcomes Research

\section{Publish your work in this journal}

ClinicoEconomics and Outcomes Research is an international, peerreviewed open-access journal focusing on Health Technology Assessment, Pharmacoeconomics and Outcomes Research in the areas of diagnosis, medical devices, and clinical, surgical and pharmacological intervention. The economic impact of health policy and health systems

\section{Dovepress}

organization also constitute important areas of coverage. The manuscript management system is completely online and includes a very quick and fair peer-review system, which is all easy to use. Visit $\mathrm{http}: / / \mathrm{www}$.dovepress.com/testimonials.php to read real quotes from published authors.

Submit your manuscript here: https://www.dovepress.com/clinicoeconomics-and-outcomes-research-journal 